\title{
751 圧電素子を利用した微動機構に関する研究
}

Step Motion Mechanism Driven by Impulsive Force of a Multi-Layer PZT Actuator

正 大内 英俊（山梨大）学○ 志村 宏（山梨大院）

Hidetoshi OHUCHI, University of Yamanashi, Takeda-4, Kofu, Yamanashi Hiroshi SHIMURA, University of Yamanashi, Takeda-4, Kofu, Yamanashi

Key Words : Multi-layer PZT actuator、Motion mechanism、Impulsive force

\section{1. 舶言}

産業界では，製品や産業機器は小形化，高性能化，省工 ネルギー化が求められている. 圧電素子は変位レンジこそ小 さいが, 発生カ・応答速度ともに他のアクチュエータよりも 優れている. 本研究では, 積層圧電素子に急激に電圧を印加 したときに発生する打撃的なカを利用して、ステップ状に移 動する機構を試作した. 摩擦のある面に移動体を置き，その 上にばねで支持された慣性体を載せて压電素子を打撃する もので，衝撃的な打撃の反カによって微小量前進し，摩擦力 のために逆戻りしない構成になっている. また、素子のセン サ機能を利用して連続的に打撃することができる(1),(2). 本稿では，この機構の基本的な特性について報告する.

\section{2、試作した機㩲の模成と原理}

2.1 模成 試作した機櫣の概観を Fig1に, 構造の概略を Fig2 に示す。この機權は，積層圧電素子 $(2 \times 3 \times 9 \mathrm{~mm})$ ，フレーム $(25 \times 25 \times 23 \mathrm{~mm})$ ，梁，慣性体 $(2.5 \mathrm{~g})$ から構成されており， 梁にはピアノ線 $(\phi 0.3 \mathrm{~mm})$ ，慣性体には黄銅を用いた. 積層 圧電素子の先端には半球が接着され，半球を介して打撃力を 慣性体に伝え，その反動で機構全体を微小移動させる仕組み になっている. また連続的に打撃力を発生させるためにマイ コンによる制御を行う.

2. 2 動作原理 Fig.3 に本微動機構の動作原理図を示す.

(a).慣性体と半球を接触させておき, 圧電素子に急激に立ち 上がる電圧 $(0 \rightarrow 100 \mathrm{~V} を 10 \mu \mathrm{sec})$ を印加し，圧電素子を伸 ばす.

(b).このとき圧電素子は，慣性体を左方向に跳ね飛ばし，同 時にその反カで压電素子が固定されているフレームは右方 向に微小移動する.

(c). 跳ね飛ばされた慣性体と压電素子が再び接触し，そのと きのカによって再度フレームは右方向へ微小移動する.

打撃あるいは衙突時は瞬間的に大きなカが作用するので 床面との摩撩力に打ち勝って移動するが，慣性体が変位し ているときのばねカは、衙撃的ではないので摩擦力以下と なり，左方向には移動しない。

2.3 連続打䡶 ここでいう連続打撃とは, 慣性体がばねの 作用で戻され，压電素子に衝突したタイミングを捉えて次 の打撃力を与えることを意味している.つまり，慣性体が 圧電素子の半球と衝突した時に, 圧電効果による電圧を発 生する. この電圧を検出し、一定の遅延時間を置き、慣性 体のリバウンドのタイミングに合わせて再ひ積層圧電素子 に電圧を印加し，連続的に慣性体を打撃している。

2.4 跠羅型锳動機模 この機構の移動性能は, 床面との糜 擦に依存している. 打撃時には, 摩摖は小さい方がよいが， それ以外は犘赠は大きい方がよい. そこで Fig.4に示すよう に, 機構の床面のフレームに傾斜(6.8 度)をつけ, 打撃方向 をやや上向きとした. 鉛直方向に跳躍させることによって摩 擦力を減少させ，移動量を增加させる仕組みになっている。

以下では、傾斜のないタイプを通常型微動機棰，傾斜をつ けたタイプを跳躍型微動機構と呼ぶこととし，両者の移動特 性の違いを実験的に調べる.

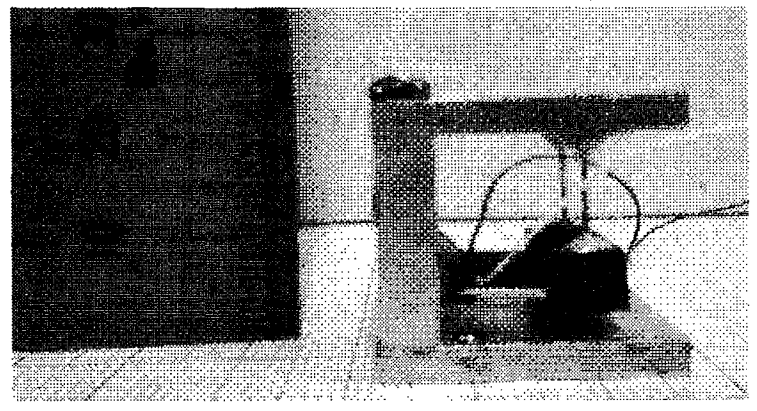

Fig.1 External view of the step motion mechanism

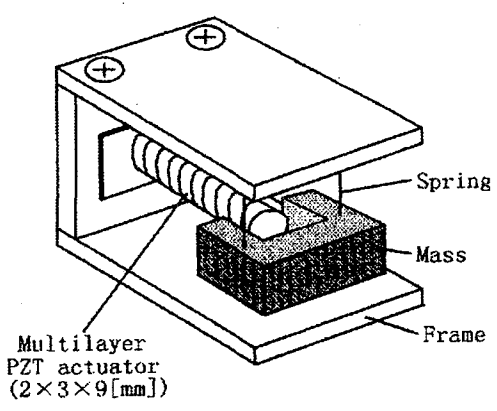

Fig.2 Step motion mechanism (a)

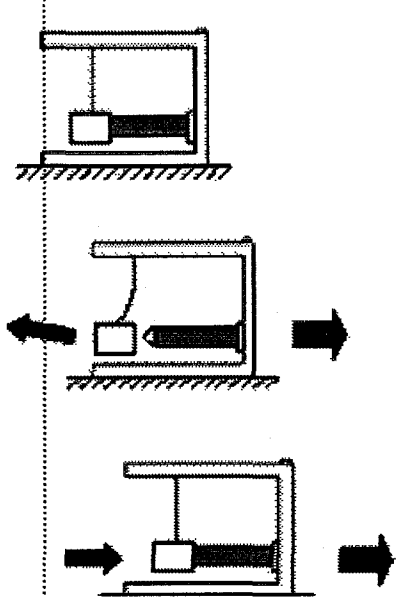

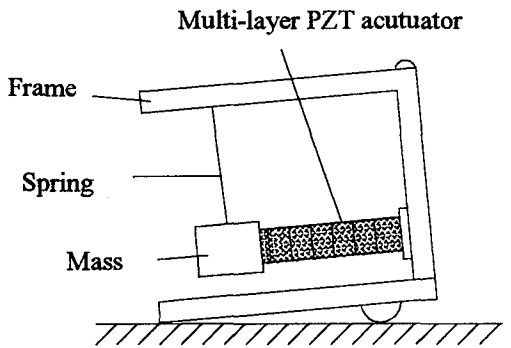

Fig.4 Jumping-type step motion mechanism
Fig.3 Principle of the step motion mechanism

\section{3. 実験結果}

微動機檕装置の特性を調べるために, 水平方向の動作、鉛 直方向の振動を、レーザー式変位センサを用いて測定した. 圧電素子には $100[\mathrm{~V}]$ のパルス状の電压を印加した．床面の 摩擦の条件を整えるために，定盤の上に方眼紙を数き，その 上を移動させた 


\section{1 水平方向の動作}

Fig.5 は通常型において 5 回連続打撃を行なったときの， 水平方向の移動状況を進行方向 (Fig.3 の右方向) から測定 した結果である. 印加電圧の大きさが不揃いに見えるが, これは測定サンプリング上の問題であり，それぞれ 100[V] が印加されている. 5 回打撃後も微動機構は移動を続けて いるのは，慣性体の残留振動によるものである。

Fig.6は，慣性体の振動を進行方向の逆から記録したもの であり，残留振動の様子が分かる.

Fig.7は、跳躍型について同様に 10 回連続打撃を行った 結果で,Fig.5 と比較すると，移動量が增している．装置に 傾斜をつけることにより装置自体が床面から離れ床面と装 置との糜擦を轻減し水平方向へのカを増加させたと考えら れる.

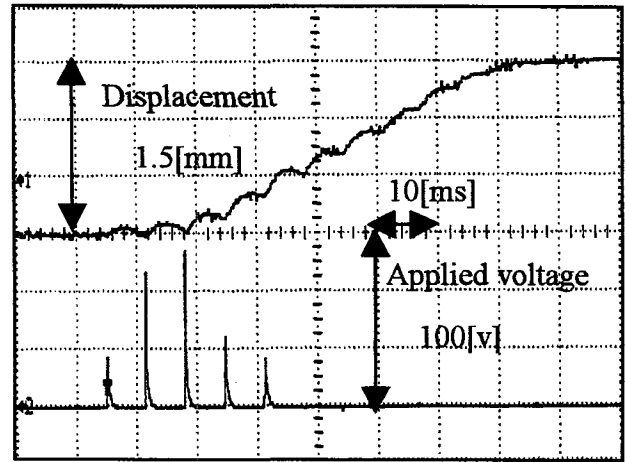

Fig.5 Displacement of the normal-type mechanism with five successive impulses

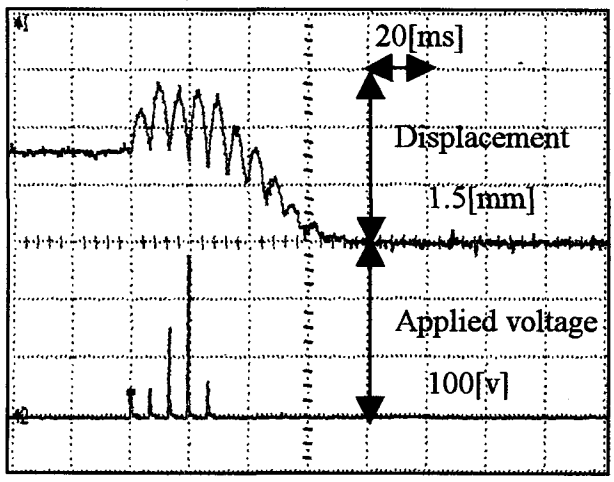

Fig.6 Displacement of inertial mass of the normal-type mechanism with five successive impulses

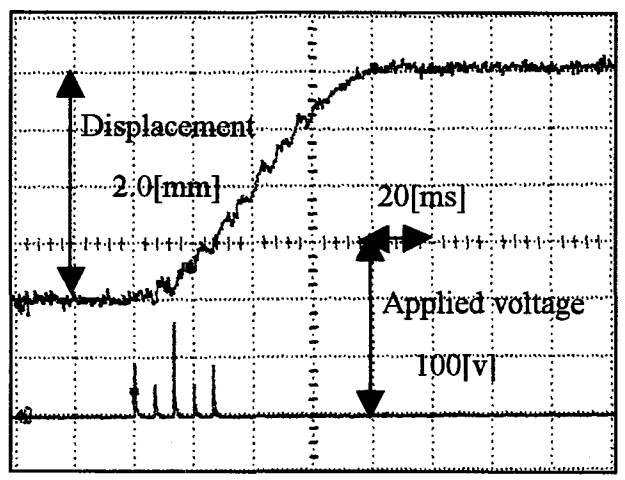

Fig.7 Displacement of the jumping-type mechanism with five successive impulses

\section{2 鉛直方向の振動}

Fig.8に跳踓型微動機栱における 5 回連続打撃時の鉛直方 向変位を示す．打撃方向に角度をつけたことにより，鉛直方 向の振動が大きく増加していることが分かる. この変位は打 撃回数を增加させると大きく増加した. また, 鉛直方向の振 動は打軗終了後残留振動によっても生じていることが分か る. なお，通常型の場合も鉛直方向の振動があったが， $0.05 \mathrm{~mm}$ 程度と小さく, 打撃回数によっては変化しなかった.

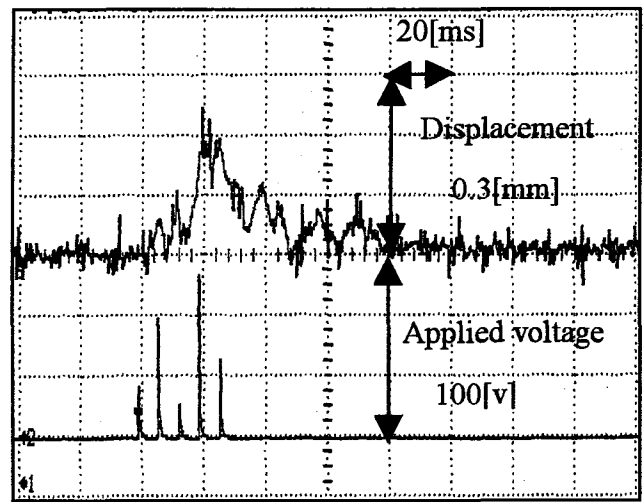

Fig. 8 Vertical vibration of jumping -type mechanism direction with successive five impulses

\section{3 負荷の積載}

Fig.9に，跳躍型微動機構の上面フレームに質量 $30[\mathrm{~g}]$ の金 属ブロックを載せ，10 回連続で打謷したときの動作を示す． 負荷の積載によって打撃回数当たりの移動量は減少したが, Fig.5 と同様の移動特性が得られている

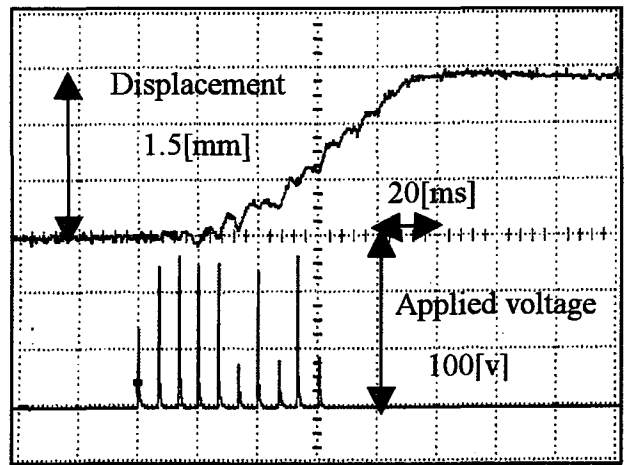

Fig.9 Displacement of the jumping-type mechanism loading mass of $30 \mathrm{~g}$

\section{4. 結言}

- 積層压電素子の打撃力を利用した微動機構においては，打 撃方向が水平方向のものに対し，やや上向きのものは床との 摩擦が減るため, 移動量が増加した.

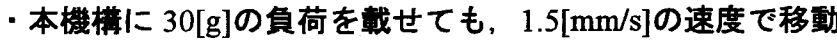
することができた.

. 今後は, 床との糜擦と移動量の関係, 積載可能な質量など について調べたい.

\section{5 . 参考文荕}

（1）大内・細田・長田，平成 15 年秋季フルードパワー システム諈演会講演論文集，(2003），141.

(2) H. Ohuchi, T. Sota and T. Osada, Proceedings of the 8th ICMT, (2004), 227 